\title{
Evolutionary Psychology as Public Science and Boundary Work
}

\author{
Angela Cassidy \\ Address: Leeds University Business School, Maurice Keyworth Building, \\ University of Leeds, Leeds, LS2 9JT \\ Phone: 01133846080 \\ Email: a.m.cassidy@leeds.ac.uk; angela.cassidy@gmail.com
}

This paper explores the phenomena of public scientific debates, where scientific controversies are argued out in public fora such as the mass media, using the case of popular evolutionary psychology in the UK of the 1990s. An earlier quantitative analysis of the UK press coverage of the subject (Cassidy, 2005) suggested that academics associated with evolutionary psychology had been unusually active in the media at that time, particularly in association with the publication of popular science books on the subject. Previous research by Turner (1980), Gieryn (1983), and Bucchi (1996) has established the relationship between such appeals to the public domain and the establishment of scientific legitimacy and academic disciplinary boundaries. Following this work, I argue here that popular science has in this case provided a creative space for scientists, outside of the constraints of ordinary academic discourse, allowing them to reach across scientific boundaries in order to claim expertise in the study of human beings.

Keywords: popular science; public science; boundary work; evolutionary theory; evolutionary psychology; publishing; UK media; natural and social sciences.

\section{Introduction: Wrestling In Public}

What happens when scientists argue in public? As with families and political alliances, on the whole, scientists tend not to wash their dirty linen in public, confining their disagreements to the more restricted space of academic fora such as journals and conferences. This leads to what Latour (1987) refers to as the 'Janus face' of science, where one (internal) side speaks of controversy, and the uncertainty and contingency of knowledge, while the other speaks of scientific truth and consensus. This bifurcation was also described by Gilbert and Mulkay (1984) as the contrast between 'contingent' and 'constitutive' aspects of scientists' discourse, depending on whether it took place in private or public contexts. Latour argues it is the task of sociologists of science to investigate the first of these, in order to understand how 'science in the making' works. From time to time, scientific controversies spread from the relatively closed and private spaces of academic journal articles, conferences and books (with small, professional audiences) to the broader public domain of less restricted mass media with far larger and less specialized audiences. ${ }^{i}$ This can often result in the uncertain and often messy internal face of science becoming exposed of its own accord. Sometimes, as with the BSE crisis in the UK, this is simply because at the time very little is known about the issue at hand, but policy or risk concerns demand answers from scientists which do not yet exist, 
pulling their already existing disagreements into the public domain. However, there are other times when scientists will seek out spaces such as the mass media for their own reasons, and use them to advance their scientific arguments and engage in (sometimes longstanding) controversies with other scientists. A particularly famous example of this phenomenon, which has now been ongoing in its modern form since at least the mid1970 s, is that of public scientific debates over evolutionary theory, as seen in the following cartoon, referring centrally to the debates between evolutionary biologist Richard Dawkins and paleontologist Stephen Jay Gould, which were principally fought out in a series of popular science books and articles written by both men. 


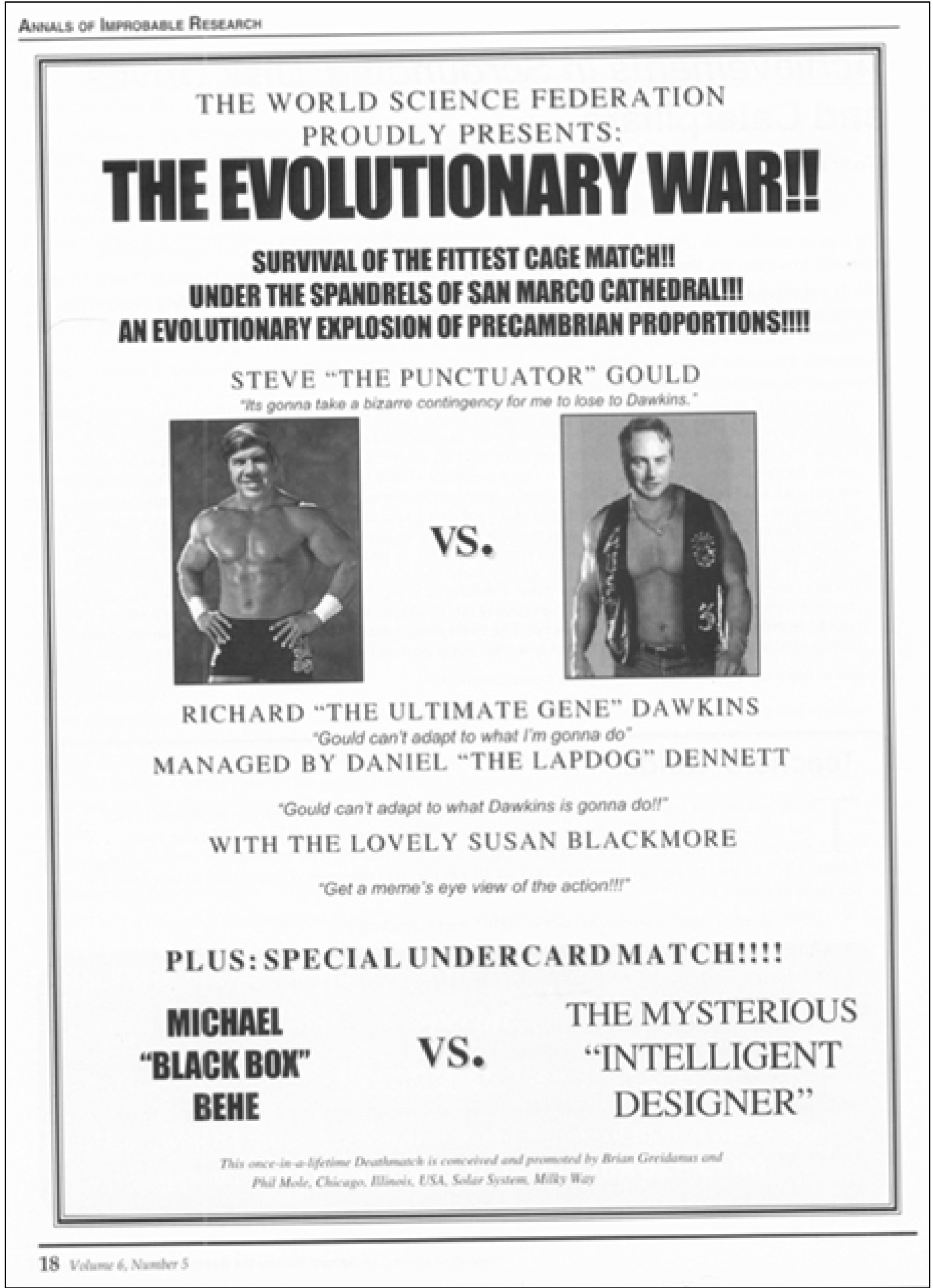

'The Evolutionary War', Annals of Improbable Research, Vol.6, No.5 (September / October 2000)

This cartoon comes from a source which could be described as 'popular science': perhaps best understood as discussions of science in media sources which have a shared and specific audience of professional scientists and non-professional readers who are interested in science. ${ }^{\text {ii }}$ It uses humor to explore this phenomenon of public scientific 
controversy, using the metaphor of a commercial, public fight, such as a wrestling match. This expresses the ambivalent relationship that many scientists have with the public domain, and with those of their number who seek to be engaged in this space, which in some ways is quite similar to the ambivalent relationship society has with professional combat sports. ${ }^{\text {iii }}$ On the one hand, these scientists are admired and valued for their abilities: in writing about and discussing their subject so clearly and articulately; in their championing of scientific causes; taking on their opponents; advancing 'the public understanding of science'; and in doing what they do well enough to be enthusiastically cheered on by onlookers. On the other hand, these public arguments could reflect badly on science: they can be seen as "squabbles", full of "hollow rhetoric, pompous quotations and insults" (Brooks, 1998; p51). Just like boxing and wrestling, it seems often the point is to win (knock your opponent out) rather than be productive or to learn anything: such activities could also be seen as egoistic, macho, over the top, commercialized, violent and ultimately pointless. Public debates of this kind draw attention to the sciences, but it also violates many of the implicit rules of scientific conduct, most notably the peer review process, but also ideas about scientific discourse being polite, subsuming personal opinions and being above commercial influences. They also, as described above, disrupt public images of scientific knowledge as certain, impartial truth, and therefore scientists who become involved in them have often faced the disapproval expressed in this cartoon, and sometimes this can translate into negative effects upon their careers (see Goodell, 1977; also Gieryn 1983). So, when faced with this kind of disapproval, or at the very least ridicule from their peers, why do scientists continue to engage in public controversy?

\section{Public science and scientific boundaries}

A useful place to start in answering such a question can be to look at other cases where scientists have worked hard at communicating in the public domain, not only in recent years but also further back in the history of science. Are there any common factors involved in such cases, in the tactics and language used by scientists when doing this work? It has been suggested that one purpose of public communication can be to help scientists establish and maintain their position as knowledge makers supported by the rest of society:

(S)cientists find they must justify their activities to the political powers and other social institutions upon whose good will, patronage and cooperation they depend. The body of rhetoric, argument and polemic produced in this process may be termed public science, and those who sustain the enterprise may be regarded as public scientists. (Turner, 1980; p589)

Historian of science Frank Turner's work, on the rhetorical strategies used by Victorian and early $20^{\text {th }}$ century scientists, illustrates how they utilized public lectures and popular writing in essays and periodicals to argue the case for the legitimacy of science, and against its' detractors, such as the church and the early antivivisection movement. Working from a similar perspective, Thomas Gieryn has explored the reasons for scientists' need to do this (Gieryn, 1983; 1985; 1999). He discusses attempts to find a set of criteria that can always distinguish science from 'not science', and concludes that they 
have been largely unsuccessful in describing any characteristics that can apply only to science all of the time. Therefore, scientists need to convince others that the work they do is legitimate, their knowledge claims are valid, that scientists should have jurisdiction over scientific knowledge, and that they should be supported by the rest of society. One way in which this can be done is to engage in arguments, described as 'boundary work', which demarcates the difference between 'proper', legitimate scientific activities and other, less legitimate ones. However, the places at which such boundaries are drawn will constantly change to fit with the needs of the argument being made and the demands of society at the time. For example, in the popular writings of the Victorian physicist John Tyndall, science's empirical, practical benefits for technological advance were emphasized when distinguishing it from religion; but its' theoretical, abstract side was stressed when separating science from mechanics and engineering.

For the same reasons that the boundaries between 'science' and 'non-science' are constructed and defended, similar rhetorical strategies can be used to create or bolster support for particular approaches or disciplines within the sciences in order to gain recognition, funding and support for their work. This can occur on many levels, from the growth of individual labs or new research programs, right up to new disciplines, and such arguments can be aimed at other scientists, funding bodies, politicians, or wider publics. Depending upon the intended audience, boundary work can appear in many places, including academic journals, policy documents, or of course the mass media. Gieryn argues that episodes concerning the interests of 'science' as a whole are most likely to be carried out in the less restricted fora of the public domain (Gieryn, 1983). However, there are times when interdisciplinary boundary work also appears in the public domain, as has been explored by sociologist of science Massimiano Bucchi (1996; 1998). Bucchi describes several case studies of scientific communication where scientists have bypassed routine methods of popularization (slowly moving from academic to mass media formats as knowledge becomes less uncertain), instead reaching out to communicate directly in popular media forms. The most dramatic example of this can be seen when scientists choose to announce their findings in press conference before they are published in an academic journal, as happened with claims of the discovery of cold fusion (Lewenstein, 1995; Simon, 2001). However, it can take other forms, such as when the Alvarez asteroid impact theory of the extinction of the dinosaurs was discussed extensively in popular forms prior to its establishment as a mainstream theory in paleontology (Clemens, 1986). Bucchi, following Cloitre and Shinn (1985), describes such processes collectively as 'deviation', and although the term is somewhat problematic, I will continue to use it here, though in a descriptive rather than normative sense.

What many of these examples have in common is the participation of members of several different scientific disciplines disputing the issue in question. For example, in the case of the Alvarez extinction theory, it was developed by a physics-geology team, but needed to be accepted by paleontologists (the usual specialists dealing with dinosaurs) in order to establish itself more fully in academia. In such cases, it can be difficult for scientists in one area to reach those in another because of the highly specialized nature of language and audiences in academic fora such as journals and conference papers. Because of their broader audiences and everyday language, mass media forms can provide alternative 
routes for communicating beyond disciplinary boundaries and reaching wider academic and other professional audiences (Dolby, 1982; Phillips, 1991). In addition, the public domain can also be utilized as a creative space for scientists, where they can operate outside of the usual constraints of academic discourse, speculating freely about their work and discussing controversial issues in ways that would not be published in academic journals without stronger supporting evidence (Felt, 2000; p30). However, such popular communication has risks as well as benefits, and scientists who engage in it can find that they are dismissed as publicity seekers, losing credibility with the very specialist audiences they might hope to reach in this way. Particularly when popular discussions result in scientific controversy becoming visible in the public domain, these activities can be highly disruptive to the public image of science as certain, reliable, knowledge. Therefore, there must be considerable pressure upon scientists before they will take this route, and Bucchi argues that a source of this can be contests over, or movements around, the established boundaries between scientific disciplines. This is signified by the presence of boundary work in the arguments in use in a controversy, which can be directed at a number of levels of scientific boundary, including those drawn around 'science' as a whole; those created as a new discipline is established; and those between pre-existing disciplines, sub-disciplines and even theoretical approaches within a single area.

\section{Evolutionary Psychology}

Another, more recent example of public scientific controversy around evolution can be seen in controversies around evolutionary psychology (EP), which appeared in the UK media during the late 1990s and early 2000s. In some ways, it can perhaps be best characterized through some of the claims made by evolutionary psychologists. These were based upon an argument that human psychology has its origins in our evolutionary history, and included claims about the evolutionary basis of monogamy, adultery, rape, the glass ceiling and what (heterosexual) men and women find attractive in a partner. The precise definition of what 'evolutionary psychology' was and is itself a controversial issue, which I will address in greater detail later in this article: however my broad understanding of the term has already been laid out in a previous publication (Cassidy, 2005). This paper also described earlier quantitative analysis of the UK press coverage of evolutionary psychology, in which it was found that this coverage showed some unusual features, compared to routine coverage of the sciences. Many more academics and book authors were writing their own articles about evolutionary psychology, rather than appearing as 'experts' cited in articles written by journalists. As time went on, coverage of the subject became increasingly evaluative and less accepting of the claims made by evolutionary psychologists, to the point where this coverage developed into a public scientific debate. In addition, a close association was found between the publications of several popular science books on evolutionary psychology, and the levels of coverage of the subject. Prior to the appearance of the first popular book to mention evolutionary psychology, science writer Robert Wright's (1994) The Moral Animal, the term 'evolutionary psychology' was not in use in the UK press at all. However, following the book's US publication, press coverage of evolutionary psychology and of the book's author rose and fell together throughout the next two years. A similar effect 
was found in 1998 and 1999, with the publication of Steven Pinker's How the Mind Works (1998), an evolutionary psychology book which was covered widely in the press and achieved high sales figures. Several of these books have relatively high citation rates in academic journals, going into the hundreds in some cases. ${ }^{\text {iv }}$ Finally, it was also found that usage of the phrase 'evolutionary psychology' in academic journal articles rose sharply after the main period of UK press coverage of the subject, which peaked in the year 2000.

However, because this analysis relied solely upon quantitative methods and data, the strength of claims that can be made based upon it is limited. A mixed methodology research design (Brewer and Hunter, 1989) was therefore employed, in which I also carried out qualitative analysis of the press and other media coverage of evolutionary psychology; and of a series of semi-structured interviews carried out with academics and media professionals involved with the controversy. A total of 21 people were interviewed between 1999 and 2002, and participants were approached through a combination of their visibility in the media, personal contacts and 'snowball' strategies." Due to the public profile of many of these people, and the 'live' and frequently heated nature of the controversy, these interviews were carried out under conditions of anonymity, despite the fact that identifying their precise position in the controversy could strengthen the analysis. Furthermore, is worthwhile emphasizing that, in line with much research carried out in the broad area of science and technology studies, I have attempted to carry out as close to a 'symmetrical' analysis of this controversy as is possible (Bloor, 1991), i.e. to address the underlying strategies and interests of all participants in the debate. This is a methodological approach which I feel is important to attempt, particularly considering the tendency of this kind of research to become incorporated into one of the sides in a live controversy (Ashmore and Richards, 1996); the heated nature of evolutionary psychology debates; and the participation of my own research fields in some aspects of the controversy. ${ }^{\mathrm{vi}}$ 


\section{Popular Evolutionary Psychology}

One of the most striking features of popular evolutionary psychology in the UK was the way in which it quickly developed into a controversy, along the lines of and blurring into previous controversies such as the above mentioned Dawkins-Gould disputes. An important aspect of this was the flexible and direct way in which the scientists and other actors involved in the controversy communicated their arguments. As well as providing interviews and quotes for journalists and press officers to write about, academics involved in the evolutionary psychology debate engaged in many more 'direct' forms of communication, such as writing press and media articles themselves, appearing on TV and radio discussion programs, giving public lectures and writing popular science books. In addition, journalists, science writers and other commentators became involved, with some actors functioning as 'experts' in the media alongside the academics.

Although not often thought of as part of the 'mass media', I would argue that popular books have often had important roles to play in the discussion of science in the public domain, despite the relative lack of attention that has been paid to them in research on science communication. In particular, such publishing has been central to the public discussion of evolutionary psychology ideas, with around 25 popular books being published in the UK on the subject, broadly defined, from 1991-2001. ${ }^{\text {vii }}$ These continue a longstanding tradition of popular writing in evolutionary thought, including Darwin's Origin of Species (1859), a book written for and read by other learned men as well as the broader educated public. The Origin was written at a time when there was much less of a division between so-called 'popular' and 'technical' writing about science. As science became increasingly professional and institutionalized through the $20^{\text {th }}$ century, it became more normal for most scientists to only communicate with one another in technical journals while only a few, usually senior, 'visible scientists' wrote books specifically intended for wider publics (Goodell, 1977). However, particularly in the evolutionary arena, popular writing continued to play important roles, with the popular work of scientists such as Julian Huxley, JBS Haldane, Ernst Mayr and Konrad Lorenz. Such discussions of evolution took on a more modern form during the Sociobiology ${ }^{\text {vii }}$ controversy in the mid 1970s, precipitated by the publication of two popular books - E.O. Wilson's Sociobiology (1975) and Richard Dawkins' The Selfish Gene (1976), and continued to be discussed at a popular level, largely but not exclusively through writers such as Dawkins and Gould, through the rest of the 1980s.

During the late 1980s and 1990s, something happened to make popular science publishing into a much more prominent, and profitable enterprise than it had been for many years, as described here by a publishing editor working in the area at the time.

When Stephen Hawking's A Brief History of Time first appeared (in 1988) anyone familiar with Weinberg's book [Steven Weinberg's The First Three Minutes] would probably have felt reasonably safe in predicting a modest sales performance at least: like the earlier book: it had a wonderful title, a straightforward writing style, and an author who was a leading light in the field. (Rodgers, 1992; p231) 
What happened instead was that Hawking's book went on to become, at the time, the biggest selling popular science book ever, taking its publishers entirely by surprise and propelling the author to fame and iconic status. Although the subsequent boom in popular science publishing cannot be ascribed solely to this phenomenon, with scientific institutions, scientists, publishers and literary agents such as John Brockman ${ }^{\text {ix }}$ all playing their part, it is certainly true that after this period many more popular books were published, prominently marketed and became bestsellers in the UK. The Aventis (formally Rhone-Poulenc) prize for science books has now been for some years a high profile event coveted by authors and publishers and widely covered in the rest of the media. This prize was set up in 1989, the year after the publication of Hawking's book, as was the Edinburgh International Science Festival, a well attended public festival where many popular authors give talks about their work, a pattern now followed by the Cheltenham Festival of Science, now in its fourth year. This pattern of trends in publishing is not unusual: another, more recent example in fiction can be seen in so called 'chick-lit', following the success of Helen Fielding's Bridget Jones' Diary (1996). However, the strength of the pop science boom was such that an entire new mass market for publishing was opened up, complete with its own trends within the genre. ${ }^{\mathrm{x}}$

During the 1990s, there was such a trend for biological, evolutionary and brain books, which evolutionary psychology fitted neatly into and benefited from, as a freelance journalist describes here, discussing a conversation that he had had with a UK publisher at that time:

"My god, something exciting's happening in science, this stuff about genetics, that sort of science, the Genome Project, and Richard Dawkins sells a lot of books, and we ought to be up to speed with this."(R9 - freelance generalist journalist)

Although, as I have described, Dawkins has been a successful popular author since the 1970s, he became even more popular at this time, as the republication of The Selfish Gene as a 'popular science classic' in 1989 attests. Furthermore, there was also a great deal of popular discussion and claims made about 'the new genetics' leading up to and including the publication of the first draft of the Human Genome Project in the year 2000, and evolutionary psychology was seen in popular science circles as closely linked to these movements. Robert Wright's The Moral Animal introduced the term 'evolutionary psychology' into public discussion in the UK in 1994, there were several other books published over this period which drew strongly upon, or were closely linked with evolutionary psychology arguments. Philosopher of science Helena Cronin's history of altruism and sexual selection, The Ant and the Peacock was published in 1992, while the science writer Matt Ridley published evolutionary books in 1994 (The Red Queen, about the evolution of sex) and 1996 (The Origins of Virtue, on altruism). Finally, cognitive psychologist Steven Pinker and primatologist Robin Dunbar both wrote on the evolution of language; respectively in 1994 (The Language Instinct) and 1996 (Grooming, Gossip and the Evolution of Language). It was also at this time that press usage of 'evolutionary psychology' and wider discussion of evolutionary themes started to take off. 
Part of the UK popular science boom included an increased popularity of events where scientists give talks, lectures, or debate with one other in front of public audiences. Such activities are not new, and public lectures have been held in this country by organizations such as the Royal Institution and British Association since the $19^{\text {th }}$ century. However, such events achieved a new frequency and popularity in the 1990s, with the Edinburgh International Science Festival and many other smaller events appearing at this time. Such events dovetail neatly with, and were frequently been sponsored by, popular science publishers, and authors with new books out are often to be found speaking at them. Evolutionary psychologists and their opponents participated fully in this movement, and in fact contributed to it via the Darwin@LSE program. Darwin@LSE was both a research group based at the London School of Economics' Centre for the Philosophy of Natural and Social Science; and a series of public lectures organized by a group of academics between 1995 and 1998. ${ }^{\text {xi }}$ The lectures were broadly on the theme of Darwinism, and many of them were given by evolutionary psychologists and their allies. Members of Darwin@LSE themselves engaged in popular work, both through books and other media. The program also produced its own series of popular science books, Darwinism Today, published by Weidenfeld and Nicholson, and co-operated closely with several publishers, in particular by timing the seminars to coincide with authors' book publications and other media appearances, but also more directly by including publisher's publicity material with that sent out advertising 'Darwin lectures'. xii

The program also networked closely with other media such as newspapers and radio, maintaining a mailing list for promoting the seminars to journalists and other interested parties. Many of the media professionals I spoke with reported receiving material from them: this was the response when I asked what this journalist knew about the program:

In the sense that I'm informed of it any time anything happens, and $\mathrm{X}$ rings up and badgers me from time to time, and certainly is a wonderful leg biter, that is whenever she sees the press, she bites their legs, and says, "Why don't you come to my lecture-ettes".

(R17 - science journalist, broadsheet press)

The lectures were very well attended, not only by members of the public, but also journalists, columnists, novelists, publishers, and other figures involved in the London media and intellectual circuit. They took place over the same early period described above, where evolutionary psychology was establishing itself, as a label and a set of ideas, in the public domain of the UK

In many ways, what was the most important aspect of Darwin@LSE was that it transformed EP from being a fairly backwater science, or discipline, or approach, to something at the forefront of the public mind. In '96, '97 it was one of the hottest tickets to have, you'd go there and you find everybody from John Maynard Smith to Jonathan Miller to Ian McEwan to Melvyn Bragg. So yes, in terms of bringing it to public consciousness, or I suppose more importantly of bringing it to the consciousness of the media and of policy makers I think it was crucially important.

(R12 - popular author, freelance science journalist)

The next major development came in early 1998, with the publication of Steven Pinker's How the Mind Works, an explicit argument for the evolutionary psychology approach to 
studying humans. How the Mind Works had a highly professional publicity campaign, and received a phenomenal amount of coverage in the UK media as a whole. As well as being reviewed in most of the daily newspapers (during the week and in Saturday editions), Sunday newspapers and news magazines, this coverage also included extracts and many other articles and comment pieces about both book and author. Steven Pinker came to Britain for the publication of the book, and conducted many interviews, book signings, radio appearances and public lectures, including at Darwin@LSE. This extensive coverage was reflected in the close association between press mentions of Steven Pinker and of evolutionary psychology throughout 1998 and much of 1999, a period when coverage of the subject became much more widespread than before (Cassidy, 2005). After the spring of 1998, the Darwin@LSE lecture series closed, and although members of the group are still resident at the LSE, they became very much less active in the public domain. xiii $^{2}$

During 1999 and 2000, a number of books appeared which changed the tenor of public discussions about evolutionary psychology from a largely positive, even celebratory atmosphere to a distinctly more evaluative one. These books were written by science writers and academics from a wider range of disciplinary backgrounds, and displayed an equally broad spread of responses to the claims of evolutionary psychology, ranging from broadly allied positions, through criticisms on various grounds, to strongly opposed arguments against EP. There was a range of responses from feminists during 1999, including US science journalist Natalie Angier's Woman: An Intimate Geography; feminist psychologist Lynne Segal's Why Feminism?; and feminist sociobiologist Sarah Blaffer Hrdy's Mother Nature. A selection of other books published at this time addressing evolutionary psychology included work by geneticist Steve Jones (Almost Like A Whale: The Origin of Species Updated, 1999); ethologists Patrick Bateson (Design For A Life, 1999) and Tim Birkhead (Promiscuity, 2000); and journalist Andrew Brown (The Darwin Wars, 1999). During this period, evolutionary psychology books also continued to appear, such as Icon Books' comic style Introducing Evolutionary Psychology, by Dylan Evans and Oscar Zarante (1999) and Geoffrey Miller's The Mating Mind (2000), but the diversity of positions now on display in the public domain meant that the overall tone of public discussion of EP had now shifted decisively towards that of a public debate, with much of the press coverage appearing in a 'controversy' framing.

One of the most overt and prominent critiques of evolutionary psychology which appeared at this time was the collection Alas Poor Darwin: Arguments Against Evolutionary Psychology, published in June 2000 and edited by the feminist sociologist Hilary Rose and the neurobiologist Steven Rose, in which academics from the social sciences, biology, psychology and philosophy wrote essays on the subject (Rose and Rose, 2000). One of the most important impacts of Alas Poor Darwin was the way in which it provided an 'event' upon which to hang press and other media coverage about evolutionary psychology. ${ }^{\text {xiv }}$ This was strongly facilitated by the activities of the editors themselves, who had been involved in previous controversies in the UK about sociobiology, and are longstanding critics of political and social aspects of the sciences. Working separately and in concert, they made themselves visible in the media through writing articles, including extracts of the book itself, book reviews, public lectures and 
debates and appearing in other media, such as radio discussion programs, to critique and argue against evolutionary psychology positions. Their work, and the appearance of the book itself, also stimulated further coverage, discussion and commentary. Just as Darwin@LSE, and the books and authors associated with it, had brought attention to EP in the first place, the Roses' book and others like it provided a focus and resource for other actors, especially lay commentators, to engage with and challenge the claims made by evolutionary psychologists.

Such patterns of media intervention and visibility occurred, to a greater or lesser extent, with all of the popular books under discussion in this paper, and indeed in terms of audience figures, it could be argued that such media coverage is at least as important, and possibly more so than the content of the books themselves, because the audiences for press discussions are so much higher. These interactions are crucially important in understanding media coverage of evolutionary psychology, as well as the broader cultural impacts of today's popular science industry.

If it's a big book, you will get book proofs ideally five to six months ahead, and those will go to magazines and you will try and pin down the cornerstones of your campaign, like serialization, color magazines and big interviews. [...] Plus, you're getting out a sort of word of mouth campaign, so you send it to major reviewers and readers, who you then get to start reading and talking about it, and you probably have anywhere between fifty and one hundred people to contact. [...] You're basically then looking at the book, taking a million notes, finding as many angles as you can, really of people who would like to review it and why, and of how many 'science' stories you can squeeze out of it for the science pages, how many 'social' stories can be spun off, implications of the science into the other pages beyond the science pages, features, arts, finance, business, columns, news, a day in the life of, if you have a strange life, personal details can be of interest, you use every angle you can, think it through and ideally you sell each angle to a different spot, so really maximizing your coverage as far as possible. (R11 - popular science PR)

I have quoted this interviewee at length to give an insight into how media campaigns surrounding modern popular science (and other) books are carried out. This co-operation between publishers and other media forms, particularly the broadsheet press and radio, are of course based in longstanding routines surrounding the publication and promotion of new books, and as such long predate the popular science boom. As well as publishers gaining exposure and publicity for their books, other media, such as newspapers, are quite happy to participate with such arrangements because it provides them with reliable, regular, predictable and frequently interesting sources of material about which to write. In the case of evolutionary psychology, it became apparent that the (often academic) authors of popular books were tapping into these routines, particularly via routes such as Darwin@LSE, in order to make their argument in the public domain, continuing the pattern of mutual co-option to the benefit of all concerned. This is highlighted by the quantitative finding that higher levels of academics were writing directly in the press compared to a similar science subject at the time (Cassidy, 2005), and many of my interviewees referred to the 'popular' or 'public' debate over evolutionary psychology. 
Although the Darwin@LSE events only ran for a few short years, largely at a time before the term 'evolutionary psychology' had gained wider currency in the UK public domain, it was clear from my interviewees that the intervention of this group provided a crucial 'push' for evolutionary psychology to enter into the public domain of the UK during the 1990s, intimately bound up with the publication of popular science books on the subject. So why did so many academics make such concerted efforts to present their arguments about evolutionary psychology in this way, rather than solely in the academic literature of the time? Although most of my interviewees felt that it was important for them to write popular science for what could broadly be termed 'democratic' reasons (sharing knowledge; furthering the 'public understanding' of science; providing feedback to society on the work they do; contributing to public debates over socio/political issues), these kinds of reasons cannot by themselves explain why so many more academics directly contributed to popular discussions about EP. Similarly, it could be argued that that the subject matter of evolutionary psychology (human psychology and relationships) is particularly appealing to media and publics alike, and that academics were simply responding to a demand for popular science in this area. Again, I believe that this may well be true, and plan to explore this issue in depth at a later date, but this cannot be the whole story: if it was then there would be many other kinds of social scientists producing popular material than there currently are. Instead, I will here focus upon broader institutional reasons why these academics turned to the public domain in this case, looking at the academic politics at work in and around evolutionary psychology. 


\section{The 'disciplinary ecology' of evolutionary psychology}

In the history and sociology of science, there have been many attempts at mapping out scientific disciplines, and the relationships between them, in order to better understand how the sciences work. However, as Thomas Gieryn's (1999) work has described, such enterprises have almost inevitably become incorporated into the processes of discipline building, in which mapping; and the associated practice of boundary work, play important rhetorical roles in creating such relationships. Inevitably, cartographers of science must occupy a particular disciplinary position themselves, and so their location will affect the way in which they draw out a map of the sciences. Furthermore, maps are designed to represent a relatively static situation, such as a landscape, and so struggle to cope with the relatively fast pace of change as the sciences develop. Gieryn suggests that perhaps a more productive way of thinking about academic science, and the complex of disciplines which make it up, can be through the use of an ecological metaphor. In a biological ecosystem, animals, plants and the environment are understood to coexist within an interconnected system in which each organism has developed a particular role, or niche from which it interacts with the rest of the system. He argues that such a metaphor can be extended as an aid in understanding society as a large dynamic system of social groups and actors, of which academia and science are a fundamental part, with their own internal 'ecology' comprised of professional disciplines: ${ }^{\mathrm{xv}}$

But science has not always had its niche, nor are the boundaries of its present niche permanent. The intellectual ecosystem has with time been carved up into 'separate' institutional and professional niches through continuing processes of boundary work designed to achieve an apparent differentiation of goals, methods, capabilities and substantive expertise. (Gieryn, 1983; p783)

Such a move has a number of advantages, but most fundamentally, an ecology is a dynamic system which changes over time, leading to an understanding of disciplinary relationships, and of society itself, as similarly dynamic. This acknowledges the importance of historical factors contributing to the present situation, as well as the likeliness of future change. The idea that today's sciences have been and continue to be shaped by their interactions with each other and the rest of society is also an important one, which has been developed further by researchers in the history and sociology of science using social worlds theory in their work (see, e.g., Clarke, 1990; 1998; Star and Griessemer, 1989). Social worlds are groups of people who work together to achieve a particular goal or goals, and produce common modes of practice in doing so. As such, the sciences can be seen as social worlds, and their mutual interactions produce and reproduce the disciplinary structures seen in modern science. An ecological (and social worlds) view of the sciences has one further advantage: it can be used to understand the multiple levels of interaction between scientific disciplines, sub-disciplines and research approaches within science, as well as the broader interactions between science and the rest of society at the same time.

Following in this tradition, I will now explore some of the ways in which evolutionary psychology challenged, destabilized, subverted, constituted and reinforced the established boundaries within and around the current social worlds of those disciplines concerned 
with studying human behavior, relationships, society and cultures. I will also use Harry Collins' concept of the 'core set' (the central, often very small group of scientists directly involved in experimentation and theorisation about a particular scientific issue) to illustrate how these boundaries exist in a series of layers radiating out from those contested around evolutionary psychology itself (Collins, 1985; Collins and Evans, 2002). These will be illustrated through examples of the boundary work performed around popular evolutionary psychology, in interviews with participants in the debate, as well as media coverage of the subject.

\section{Evolutionary Psychology: the core-set}

When conducting interviews for this research, I quickly found that asking actors to give a definition of evolutionary psychology was a simple and rather revealing way of beginning, providing a good way of engaging people whilst breaking the ice in a new encounter. I rapidly found that many people struggled with their answers, and sometimes actively resisted my attempts to find out what they thought 'evolutionary psychology' meant. The answers I got back were enormously varied, as indeed are the descriptions and definitions of evolutionary psychology that have appeared in print. In fact, as this answer suggests, it may be this very quality which has helped evolutionary psychology in gaining currency in both popular and academic discussions of the subject.

What it [evolutionary psychology] is actually, it is the attempt to put forward evolved adaptations in the human mind [...] I think in pop terms, I mean my own rough... Like any catchphrase like that, it's also an aspiration, it's a research program, it's a, you know, it's practically got a tool for picking things out of horses hooves! (R1 - popular author and freelance science journalist)

Of course, there is a certain paradox in attempting a description of evolutionary psychology in a article analyzing the arguments and rhetorical devices used in just such definitions. Like Gieryn's cartographers of science, I have an inescapable, albeit complex location in these debates, which will in turn affect my analysis. ${ }^{x i}$ However, my description of these relationships should be understood as not only partial, but also as a snapshot of a dynamic and rapidly changing situation. Also, rather than trying to define the boundaries of 'evolutionary psychology', I would instead like to describe my understanding of the 'core-set' of actors, locations and concepts associated with the subject, which I have done by tracing them back to the origins of the term itself.

The first people to write about evolutionary psychology, and the originators of the label in the late 1980s were a small group of North American cognitive and social psychologists and anthropologists. This core group included two central research teams: psychologist Leda Cosmides and anthropologist John Tooby; and Canadian psychologists Martin Daly and Margo Wilson; as well as social psychologist David Buss; cognitive psychologist and linguist Steven Pinker; and anthropologist Donald Symons, who was involved with sociobiology since the late 1970s. In the wake of this group, many other academics have adopted their ideas, based in a wider range of disciplines: still in 
psychology and anthropology, but also in philosophy, economics, law, management and advertising. This second group is also more geographically distributed with a strong presence in the UK as well as US, although with far fewer representatives outside of the Anglo-American world. Examples of UK core actors include the members of the original Darwin@LSE group such as Helena Cronin, Geoffrey Miller and Dylan Evans, as well as philosophers such as Janet Radcliffe Richards. I would argue that this second group has also included prominent science writers such as Robert Wright and Matt Ridley, who have been very active in contributing to and promoting evolutionary psychology through their books and writing in the UK media. Today, the most important academic society for evolutionary psychology is the Human Behavior and Evolution Society (HBES): its journal Evolution and Human Behavior has been one of the central academic sites for publication on the subject. ${ }^{\text {xvii }}$ Other important journals include Behavioural and Brain Sciences, and Human Nature: an Interdisciplinary Biosocial Perspective.

So what do evolutionary psychologists themselves say when they are trying to define what they do? The following statement comes from what one of my interviewees described as a 'manifesto' for evolutionary psychology, written by Leda Cosmides and John Tooby, arguably the originators of the term, and authors of the first academic papers to use it.

Evolutionary psychology is an approach to psychology, in which knowledge and principles from evolutionary biology are put to use in research on the structure of the human mind. It is not an area of study, like vision, reasoning, or social behavior. It is a way of thinking about psychology that can be applied to any topic within it. (Cosmides and Tooby, 1997; p1)

Although science writer Robert Wright described EP in his book The Moral Animal (1994) as a 'new science', Cosmides and Tooby avoid such concrete definitions, and often resist characterization of evolutionary psychology as a discrete discipline. In other places, they and others have referred to it as a 'new paradigm', either for psychology or the social sciences more widely (e.g. Barkow, Cosmides and Tooby, 1992; Buss, 1995). The following image comes from an online resource of essays about the philosophy of mind, which uses cartoons as a way of highlighting the central concepts of each essay. In this case, the cartoonist reinforces one of the most central concepts and definitions given by the proponents of evolutionary psychology. This, as suggested by the name itself, is that evolutionary psychology is 'the combination of two sciences - evolutionary biology and cognitive psychology' (Evans and Zarante, 1999; p 3) or as indicated here, what happens when Darwin and 'the brain' get together. 


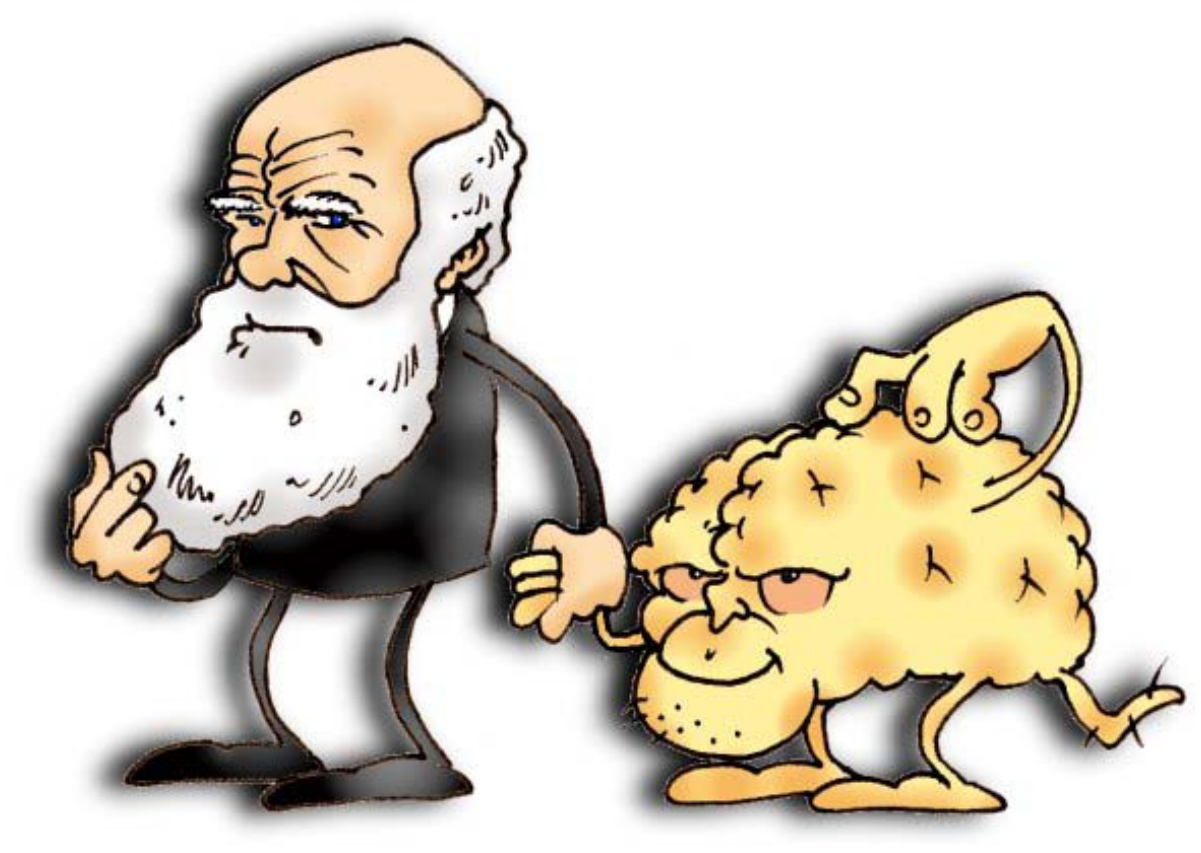

Image by Enrico Biondi, taken from essay, 'Evolutionary Psychology' on the website $A$ Field Guide to the Philosophy of Mind ${ }^{\text {xiii }}$

Such initial definitions are often quite broad, but closer examination reveals several theoretical ideas which distinguish evolutionary psychology from other evolutionary approaches to humans. The second image comes from a popular science website, Evolution's Voyage, and illustrates some other defining characteristics of evolutionary psychology ideas.

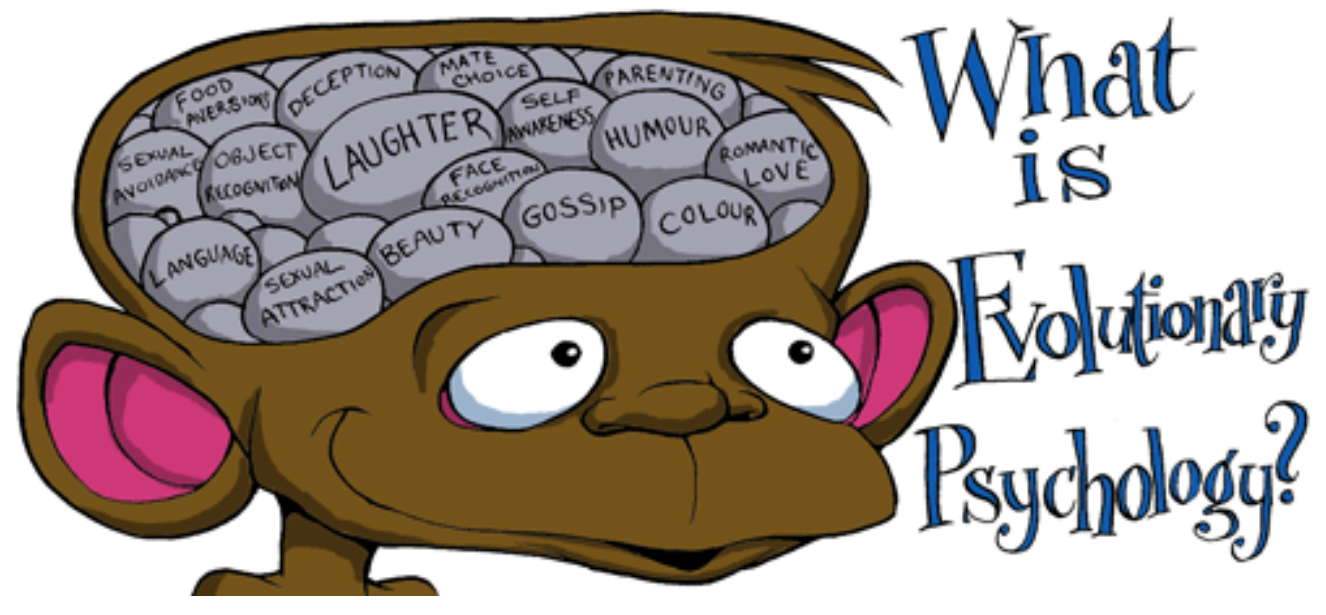

Image by Alex Hughes, taken from, 'What is Evolutionary Psychology?' on the website Evolution's Voyage $^{\text {xix }}$ 
Again, the image of the exposed brain is important as a symbol of the object of study of cognitive psychology. Cognitive psychology has traditionally been an area of psychology strongly aligned towards the natural sciences, often using models of the mind based on computing metaphors and allied with neuroscience, computer science and artificial intelligence. As with the previous image, the exposed brain represents the mind and the two are seen as synonymous, reflecting the materialist stance of cognitive psychology. The circles labeled 'laughter', 'language', 'sexual attraction' and so on indicate a specific model of the mind held by evolutionary psychologists: massive modularity. The massive modularity thesis sees the mind as made up of many independent units, each of which handles a specific task, such as language. This model was developed out of earlier ideas about modularity developed in cognitive psychology (Fodor, 1983), but massive modularity is still controversial within that discipline (e.g. Fodor, 2000). The representation of these modules is interesting, with the grey color and three dimensional shapes recalling the exposed physical brain, but the labeled circles on the brain's surface also recalls the $19^{\text {th }}$ century study of phrenology, which evolutionary psychologists often claim as a precursor to their own science (see, e.g., Evans \& Zarante, 1999; $p$ 37). ${ }^{\mathrm{xx}}$ The image also looks to be one of a monkey, thereby symbolizing human origins and links with other animals, as well as evolutionary psychology's connections with biology through evolutionary theory. The addition of Darwinism brings evolutionary psychologists further towards the natural sciences, thus lending them the relatively greater epistemological authority of biology. Another important concept is the idea that 'our modern skulls house a Stone Age mind' - that our minds are adapted for an ancestral environment and haven't changed since (though the environment has), sometimes paraphrased as 'caveman psychology' (Cosmides and Tooby, 1997). Finally, evolutionary psychologists also stress their interest in the universal features of human psychology and behavior, rather than in differences between groups of people, such as ethnic groups, an important distinction I will return to later.

\section{'Broad' and 'narrow' evolutionary psychology}

However, these definitions of evolutionary psychology as laid out by its proponents in the US and UK, are frequently contested by other actors with an interest in the area. As well as the core evolutionary psychologists, in the UK there are a broader spread of academics exist who, like evolutionary psychologists, use evolutionary theory in their work and study human beings, but do so using a broader variety of theoretical models and empirical methodologies. These researchers also come from a different grouping of academic disciplines, ones more traditionally associated with evolutionary studies, such as neurobiology, evolutionary biology, physical and paleo anthropology, behavioral genetics, paleontology, ethology (the study of animal behavior), and primatology. In general, these disciplines are better established in academia than evolutionary psychology, but are also the origin of many of the theoretical concepts currently in use by evolutionary psychologists. On the whole, these researchers have in common an orientation, location or history leaning towards the biological natural sciences, and to the theoretical approaches of sociobiology and behavioral ecology. The complexity of the situation is such that I can only give here a generalized sense of these relationships, but it is also one in which the notion of a disciplinary ecology can certainly be applied, with the 
associated ideas of constant change and interaction between the actors and groupings concerned.

The term 'sociobiology' was coined in 1975 by the American entomologist E.O. Wilson in his book Sociobiology: The New Synthesis, in which he described his vision of how to apply the concepts of evolutionary biology to the study of behavior. As the title suggests, the book brought together empirical research on animal behavior whilst showing how those findings were consistent with theoretical ideas in evolutionary biology. It was his final chapter, in which Wilson extended these arguments to humans, where the trouble started. The Sociobiology debate, largely sustained from the mid 1970s until the late 1980 s, had many features in common with 1990s controversy over evolutionary psychology. It was launched and sustained through a number of semi-popular books and 'public' events; involved protracted, bitter and public controversy between academics from a range of disciplines; and was concerned with contemporary political issues, as well as the boundary between the natural and social sciences. A full discussion of the Sociobiology controversy is far beyond the remit of this paper; however, it is important for understanding the current situation to take this previous episode into account, as well as to understand that sociobiology did not begin, end or exclusively comprise the writings of E. O. Wilson. In parallel and prior to the American work of Wilson and his colleagues, the British tradition of ethology (animal behavior) research had developed alongside theoretical evolutionary biology to create something very like Wilson's Sociobiology: the more UK based tradition of behavioral ecology. In 1976, the then ethologist Richard Dawkins published the classic work of popular science, The Selfish Gene, describing a view of evolution as operating at the level of individual genes, rather than organisms, populations or species. The traditions represented by Wilson and Dawkins were interrelated from the start and rapidly moved together to strongly influence many areas of biology, but particularly 'whole organism' disciplines, such as population biology and studies of animal behavior. This means that although public disputes over Sociobiology and humans have long since subsided, in academia there are many scientists who would still describe themselves as sociobiologists or behavioral ecologists (see Brown, 1999 and Segerstrale, 2000, for further discussions of this period).

In her research on the history of primatology, Amanda Rees argues that primatologists adopted sociobiology in the 1970s and 1980s because it provided a strong theoretical framework for a field of study that had previously worked largely within an empirical, descriptive 'natural history' tradition (Rees, 2001a; 2001b). This theoretical framework helped to bring primatology further towards the natural sciences and reinforced its status as 'science', rather than the atheoretical, semi-amateur Victorian tradition of natural history. This holds for not only primatology, but also for studies of animal behavior in general, as described here by one of Rees' informants:

Sociobiology, or what can be spoken of, "more broadly under the label of behavioural ecology, what it boils down to is asking not just the old question of what do the animals do but in addition, asking the question, 'If they are well adapted, what should they be doing and how close does the one match the other?' This is the kind of thinking that has really 
revolutionised animal behaviour in general, not just primate field studies." (Rees, 2001a; p233)

It seems more than possible that psychologists, who tend to work in one of a half-dozen or more competing schools of psychological thought, may feel a similar need for unity and a more coherent theoretical underpinning to their work (e.g. Richards, 2002). These comments also highlight the ambiguity felt by many academics around the term 'sociobiology', with 'behavioral ecology' sometimes being adopted as an alternative name for the area. This is particularly common amongst UK academics, where the behavioral ecology tradition developed, but the boundary between the two is quite flexible, as I found when exploring it with my interviewees. Academics identifying closely with evolutionary psychology seemed aware of the term 'behavioral ecology', but were very unclear on what it might mean. Some felt that the two were synonymous, or that it was pointless trying to make such distinctions, whilst others (tending towards the ethology tradition) seemed much keener to make a strong distinction between the two. At the same time, there were others who quite pragmatically identified the 'behavioral ecology' label as a tactic used to avoid the public notoriety or political connotations of sociobiology, or to distance a British research tradition from a North American one.

So when developing their arguments, evolutionary psychologists had to emphasize the newness of their approach, and its difference from the many others in this crowded arena. One of the key ways in which this was done was to stress the importance of (human) psychology in evolutionary psychology, as compared with the sociobiology / ethology tradition of studying animal and human behavior, hence the emphasis on the human mind/brain in the above definitions. This movement between 'general' and 'specific' definitions of evolutionary psychology is well illustrated in this comment from a 'core' EP academic and popular author:

It's just Darwinian theory applied to human beings, that's all, just as simple as that. I think the one thing I would add, is that there are so many wrong ways of applying it in general to any species, and to any problem, but in particular people seem to find even more wrong ways of doing it when you get to humans. But this, the key that this approach has developed and is obviously right, is not to try to explain human behavior as the adaptations, but to look at the adaptations in the mental and physical adaptations that natural selection has laid down, and then those generate forms of behavior, and different behavior under different conditions, and one of the problems is to look at, given this mental inheritance and psychological inheritance, under what sorts of conditions might you expect what to occur. It's just being Darwinian, at humans. (R3 - academic, evolutionary psychology; popular author)

This response also emphasizes the contributions of cognitive psychology to evolutionary psychology, important in the theoretical concept of massive modularity, and some of the methodological approaches used in EP research. Part of the reason for this distancing can be seen in the arguments of opponents of evolutionary psychology, who tend to describe it as part of a much larger continuum of evolutionary approaches to studying humans, as seen here:

Look, I mean I date the whole recent, sort of the whole history of the current interest in sociobiology, evolutionary psychology right back through the 1970s. Really I would date its 
In press for a forthcoming issue of Public Understanding of Science: please do not cite or quote

starting point to when Jensen wrote his paper on IQ, back in 1969. (R18 - academic author, neurobiology)

This view of evolutionary psychology, as continuous with previous 'biological' approaches to humans, serves obvious rhetorical purposes, by linking it with more politically conservative traditions such as race-IQ theory, social Darwinism and eugenics (see, e.g., Dusek, 1999; Rose and Rose, 2000 for similar views).

However, the boundary between sociobiology and evolutionary psychology was also regarded as weak or unimportant by other academics involved in evolutionary studies, who were not direct opponents of evolutionary psychology. For example, in this interview with Richard Dawkins, carried out by the evolutionist, Darwin@LSE's online magazine, ${ }^{\mathrm{xxi}}$ Dawkins is skeptical of evolutionary psychology's claims to novelty:

the evolutionist: Surely there's quite a difference between the way evolutionary theory is used in evolutionary psychology, than the kind used in the less sophisticated areas of sociobiology?

Dawkins: $\quad$ So you say; it's not obvious to me. Sounds like a new name for the same subject. What do you think is the difference?

the evolutionist: The main difference is surely the emphasis on psychology... (Curry, 1997)

Dawkins' view was reflected by those of many of the people I spoke to with a longstanding research involvement with evolution and humans: that evolutionary psychology is basically the same thing as sociobiology. Others were skeptical of the need for this kind of labeling, questioning the utility of 'marching under banners', or using 'cheap slogans'. The following comment, from an academic involved in sociobiological research for many years, reflects this ambivalence:

I was an evolutionary psychologist before the word had been invented [...] and I think I didn't notice what was happening, that in other people's minds evolutionary psychology had come to mean a much narrower branch of science, that not only was about the issues of evolution and psychology, but a particular theoretical framework [...] So I've been in a bit of a dilemma, I don't want to abandon the term evolutionary psychology [...] But it's become a bit of an albatross, because it now identifies you with a particular church within this field, many of whose ideas I don't actually hold with. (R10 - academic, sociobiology, psychology; popular author)

Often this discussion was conducted in terms of there being 'broad' and 'narrow' versions (often termed 'churches') of evolutionary psychology, with several actors, expressing the hope or belief that the publicly visible label could be co-opted by a broader movement of more varied approaches to evolution and humans. ${ }^{\text {xxii }}$ At other times, a more pragmatic boundary was drawn by assigning 'sociobiology' to the evolutionary study of animals, and 'evolutionary psychology' to the evolutionary study of humans.

In spite, or perhaps because of all the distinctions made by academics, media professionals expressed quite different attitudes: 
I don't think the majority; certainly the majority of the mainstream media really have the sophistication to distinguish between evolutionary psychology, social Darwinism, social biology, ordinary, in inverted commas, psychology. I think all these things tend to be sort of bundled up together: when I do pieces or with the World Service do pieces, which touch evolutionary psychology, we do make the distinction [...], but that distinction is not always clear, or is sometimes difficult to make. (R14 - radio producer, science broadcaster)

Although most seemed aware of the stated differences between sociobiology and evolutionary psychology, they felt that such boundary attempts were at best difficult and at worst unimportant and unhelpful when trying to discuss evolution in media contexts. This is reflected in media coverage of the subject, where the term itself was sometimes avoided to concentrate instead on the specific issues at (for example, gender differences). So if these distinctions are not made in the public domain, then why is it important to understand them at all? The label of 'evolutionary psychology' has quite clearly become a publicly recognized term, and one that has now largely eclipsed 'sociobiology', at least in UK press coverage (Cassidy, 2005). Therefore, the ability to own this label, to be identified with it in the public domain as well as in academia, is a powerful one, and something that actors in popular evolutionary psychology have vied to attain. 
As I have described, the core-set of evolutionary psychologists tended to work in disciplines such as cognitive psychology or parts of philosophy; areas which are strongly oriented towards positivism and the natural sciences, particularly via subjects such as artificial intelligence. However, these subjects are at present mostly located in social science, humanities, or perhaps in computer science departments, whereas researchers in 'broad' evolutionary psychology work in a complex of disciplines around and in the biological sciences. Many academics in these disciplines, who have been working in the area for many years, have an ambiguous relationship with evolutionary psychology, whereby they feel broadly allied to it through a shared commitment to evolutionary theory, but feel uncomfortable in being identified too closely with it. At the same time, the mainstream of most social science disciplines, such as psychology or sociology, do not use biological or evolutionary ideas, and generally look to psychological, social, political and cultural explanations for understanding why people do the things that they do. For example, ideas about the social construction of gender stress the roles of upbringing, social norms and cultural experiences in creating modern systems of gender and sexuality, rather than evolutionary forces. Another important area of difference can be seen in the current emphasis in the social sciences and humanities on the importance of differences and variations across cultures and historical periods, as opposed to EP's interest in 'human universals'. This means that social scientists using evolutionary ideas have tended to be in a minority within their own disciplines, leaving many evolutionary psychologists in isolated or marginalized positions. An indication of this feeling can be seen in evolutionary psychologists' frequent use of the following quotation, from philosopher of science Max Plank.

A new scientific truth does not triumph by convincing its opponents and making them see the light, but rather because its opponents eventually die, and a new generation grows up that is familiar with it. (Planck, 1949; p33-34)

This was quoted several times during interviews with evolutionary psychologists, as well as, for example, in discussions on a widely used mailing list, usually in the context of relations with other social scientists. ${ }^{\text {xxii }}$ The implications here seem to be twofold: that it is not possible to convince their opponents of the rightness of their arguments; and that persuasion of students and younger scientists might prove more promising.

During the 1970s, E. O. Wilson argued that Sociobiology provided the means for a 'scientific' study of human behavior, in which the social sciences would ultimately be subsumed into the natural sciences (in the form of biology). ${ }^{\text {xiv }}$ In response to these and similar ambitions, the sociologist Hilary Rose asks whether evolutionary psychology is "colonising the social sciences?", and concludes that this is indeed the case (Rose, 2000). Although this seems a fairly accurate description of the ambitions of Wilson and many early sociobiologists, it does seem that evolutionary psychologists' attitudes to social science may be more complex. Sociobiology was and is practiced most often in the (biological) natural sciences, whilst a definite new feature of evolutionary psychology is its presence and origins in the social sciences, albeit positivist traditions within those 
disciplines. In The Adapted Mind (1992), an edited book laying out the basic premises of evolutionary psychology, EP is described as a 'new paradigm' for the social sciences, suggesting something a bit different from Wilson's decidedly colonialist ambitions. Rather than subsuming the social sciences into biology, the intent seems to be to maintain the social sciences as separate disciplines for studying humans, but to instead transform how this is done. Hence the mobilization of Kuhn's (1962) imagery of 'scientific revolutions' and 'paradigms', which, in this context also fits well with the usage of Max Planck (adding the implication that evolutionary psychology can transform the social sciences from within). In the first chapter of The Adapted Mind, Tooby and Cosmides set out a critique of what they described as the 'Standard Social Science Model' (SSSM) of studying how humans work. They characterized this model as one ignorant of the role of biology and evolution in forming human minds, behavior and culture, thereby cutting off the social sciences from the natural sciences. What emerges from the piece is less of an attack upon all social science per se, than a critique of interpretive and qualitative approaches to social and psychological research. Experimental approaches, utilized more frequently in psychology, (especially cognitive psychology) and physical anthropology, are held up as better, more 'scientific' alternatives throughout the rest of the book (Barkow, Cosmides and Tooby, 1992). This attack must be seen in the context of longstanding splits in the social sciences: roughly between interpretive and positivist research philosophies; and broadly corresponding divisions between quantitative and qualitative methodologies. A very rough characterization of these positions might be that positivist approaches attempt to study humans in the same way as the rest of the natural world, using (largely) quantitative data and experimental methodologies. Interpretive approaches stress the importance of meaning and intention in humans' thoughts and actions, arguing that we need to be studied in different ways to the natural world, with a greater emphasis on qualitative data and different methodologies such as interviewing, analysis of discourse and ethnography (Hughes, 1990; Malik, 2000).

Such conflicts within the social sciences can be seen most sharply in anthropology, where physical anthropologists use quantitative measures of people and cultures, whilst most social anthropologists reject these approaches and instead investigate the particularities of contemporary human cultures, using participant-observation techniques and ethnography instead. This split is perhaps one of the most severe in the social sciences, with the two groups rarely communicating, and controversy between the two becoming increasingly acrimonious. ${ }^{\mathrm{xxv}}$ Interestingly, it is physical anthropologists such as John Tooby and Donald Symons who provide the most direct links between the (mostly) older sociobiology and (mostly) younger evolutionary psychology research communities. Parallel arguments have developed in the humanities, where newer, socially influenced perspectives on the history and philosophy of science are still strongly contested by traditional positivist philosophers of science; many of whom also work in philosophy of mind (closely aligned to cognitive psychology). ${ }^{\text {xvi }}$ With this in mind, it is perhaps less surprising that there were also links between evolutionary psychology debates and the science wars in the UK: two of the most prominent 'science warriors' in the UK, Richard Dawkins and Lewis Wolpert, are both allied to evolutionary psychology. A 'science wars' book was written by one of the few professors of evolutionary psychology in the UK (Dunbar, 1995); and the topic was frequently discussed on the evolutionary 
psychology mailing list (which science warrior par excellence Paul Gross also subscribes and contributes to). Finally, the last of the Darwin@LSE seminars in 1998 was a public debate between Alan Sokal and Bruno Latour. Sociologist of science Ullica Segerstrale remarks upon this in her history of the sociobiology debates, arguing that the science wars were a struggle for 'the cultural authority of science' (Segerstrale, 2000; p340). ${ }^{\text {xxvii }}$ This would concur with Thomas Gieryn's conclusion that the science wars controversies were themselves episodes of boundary work, in which the traditional autonomy and authority of science were defended, whilst attacking the legitimacy of social scientists to be studying the content, practices and conclusions in the first place (Gieryn, 1999; 336$62)$.

Despite such conflicts, interpretive social scientists have not on the whole become very involved in public controversies over evolutionary psychology in the UK. Neurobiologists, geneticists and sociobiologists have all become involved, while those sociologists and interpretive psychologists acting in the public domain have largely been feminists, more directly concerned with the gender aspects of evolutionary psychology arguments. A possible exception to this might be Anthony Giddens, director of the LSE, and during the 1990s one of the most publicly visible sociologists in the UK, who has argued on his website for the need to defend the social sciences "against the current trend toward the natural sciences" (Giddens, 1999). However, I have not come across any other public intervention from him on the subject, nor have I observed many other interpretive social scientists arguing against evolutionary psychology in popular forms or public spaces such as the mass media. Considering the ferocity of evolutionary psychology's attacks on the interpretive social sciences, this lack of visible response is curious, and should perhaps be a cause for concern in these subjects, especially in the light of opinions such as these:

I think evolutionary psychology has a tremendous amount to offer to the social sciences, the old-fashioned social sciences, in fact I don't think they can do without it. I mean, basically sociology is terribly short of ideas, talk to Anthony Giddens or someone and try to find some interesting intellectual ideas there - it won't work, because there's nothing there. (R10 academic, sociobiology, psychology; popular author)

Giddens' near solitary position as a 'visible sociologist' in the UK meant that he often became, by default, representative of all social sciences in this country. As such, his political stance and close alignment with the Blair government is of particular concern considering natural science critiques of the social sciences as contentless and politically loaded. An important part of the 'turf wars' being carried out around evolutionary psychology is, like many past disputes over evolution and humans, a conflict between the natural and social sciences. However, unlike previous episodes such as the Sociobiology debate, this is also, very importantly, a conflict between two radically different visions of, and approaches to, the social sciences. Evolutionary psychology's version of social science is a positivist, scientific (or scientistic) one, and it is crucially engaged in an attempt to convert both internal and external understandings of the social sciences to match that vision. 


\section{Evolutionary Psychology as 'Science'}

Finally, evolutionary psychology often breaches the boundaries generally drawn around science, separating it from the rest of society, as described above in the work of Turner, Gieryn and Bucchi. This has happened in two important, but really quite different ways. Firstly, evolutionary psychology's subject matter (studying humans) brings it intrinsically closer to the non-scientific worlds of politics and everyday knowledge about people.

Secondly, the movement of evolutionary psychology debates into the public domain has brought with it the attendant risks faced by any scientist undertaking popular work: that they will lose credibility in the academic domain. This wobbly line, between academic and popular science, is one that both evolutionary psychologists and their opponents have walked during the course of the debate.

If, as Donna Haraway (1986) has argued, "primatology is politics by other means" because the scientific study of apes and monkeys so often becomes an allegory for human politics and society, then surely evolutionary psychology, the scientific study of humans, must run the risk of being seen as 'simply politics'? Indeed, the evolutionary psychology claims which have received the most public attention have on the whole been intensely political ones, albeit not in the conventional sense of 'party politics'. Claims about the nature of heterosexual desire and gender differences; the root causes of child abuse; and the origins of the 'glass ceiling' are all inherently political. This is especially true when they are presented as speaking to policy and policymakers, as happened when Darwin@LSE launched its program in a joint publication with the UK liberal/left thinktank Demos. ${ }^{\text {xxviii }}$ Such proximity to the political arena has given rise to one of the most important criticisms of evolutionary psychology (also at stake in previous controversies about biology and humans), that such science is biased towards, or can provide scientific justifications for particular political agendas. An important distancing tactic and counterargument used by evolutionary psychologists is the invocation of a philosophical principle known as the 'naturalistic fallacy'. This principle, originating in the arguments of David Hume and G.E. Moore, argues that it is a mistake to infer an 'ought' statement (of how a particular situation should be) from an 'is' statement (of how things actually are) (Radcliffe Richards, 2000; p230). Following this, evolutionary psychologists argue that their science merely investigates the 'is' of human nature, and says nothing about the 'ought' - i.e. political or moral arguments about how people should live. Such arguments help to demarcate between the claims that evolutionary psychologists make about people and the political implications of these claims, or the uses that others might make of them. ${ }^{\text {xxix }}$ It bolsters evolutionary psychology claims of making objective, scientific truths about human nature, and delegitimizes criticisms of evolutionary psychology made on political grounds (that EP is sexist, racist, and so on), by making critics guilty of committing this fallacy and of being motivated by politics or even 'ideology', rather than science or a concern for the 'truth'. The naturalistic fallacy is often treated as if it is a law of nature, without any discussion on why it is a mistake to infer how things should be from a statement of how they are. However, within the evolutionary community, this principle is not universally accepted, most notably by E. O. 
Wilson himself, who argues that all human endeavors, including politics and morality, should be derived from science (see Wilson, 1998; Segerstrale, 2000; ch.18).

As well as constructing a demarcation between itself and the domain of politics in general, evolutionary psychology must distance itself from conservative politics in particular. This is a particularly important part of the boundary work carried out between evolutionary psychology and sociobiology, because of the very strong impacts of earlier leftwing critiques of sociobiology ideas. Evolutionary psychologists have done this by associating themselves with liberal / left politics, particularly during the early New Labour (UK) and Clinton Democrat (US) era of the mid and late 1990s. As well as their work with Demos during this period, a thinktank formed just prior to Labour's election to power in 1997; a good example of this general strategy can be seen in the Darwinism Today publication A Darwinian Left, written by philosopher Peter Singer (1999). Similarly, several evolutionary psychologists have written of themselves as feminists, and argued that their ideas are compatible with feminism (see, e.g. Cronin, 1999). Finally, evolutionary psychologists have had to create a boundary between themselves and evolutionary arguments about race in particular. This is largely because of the long history of evolutionary thought about race, which continues into the present day with behavioral geneticists' arguments about race and IQ, still visible in the public domain (Herrnstein and Murray, 1994). Evolutionary psychologists argue that they are only interested in features which are 'human universals', not in individual or group differences, and so are not interested in race. This position is underlined by their adoption of Dawkins' (1976) arguments that evolutionary selection occurs at the genetic, rather than group level. Some evolutionary psychologists even claim to be researching the evolutionary underpinnings of racism itself, in order to help combat it (Kurzban, Tooby and Cosmides, 2001). As with the use of the naturalistic fallacy, this boundary is also squishy on

The movement of the evolutionary psychology debate so strongly into the public domain has also meant that participants have had to negotiate the fine line between legitimate 'popularization' and less legitimate publicity seeking, sensationalism, egoism and so on, as lampooned in the Evolutionary War cartoon discussed at the beginning of this article. In recent years there have been significant shifts, especially in the UK, in the location of this boundary with government, funding bodies and scientific institutions all offering advice, support and incentives for scientists to communicate their work in the public domain. The popular science boom of the 1990s has also made it much more respectable for scientists to engage in popular communication. Such shifts can also be seen in exemplary events, such as the election of Richard Dawkins as a Fellow of the UK's Royal Society in 2001, 'for his work on evolution and for raising the public understanding of science' (Royal Society, 2001). Although the space for legitimate popular science is probably far bigger today than it has been for many years, scientists do still need to protect their domain of expertise, often by using popular science itself as a tool to do this (e.g. Mellor, 2003). There are still potential risks for scientists in undertaking popular communication, as described by this senior academic: 
In press for a forthcoming issue of Public Understanding of Science: please do not cite or quote

So it can be a mistake for academics to think they can do what John Brockman says they can do, which is go directly to the public with their ideas [...] It can be a mistake for scientists to do this and I think it can particularly be a mistake for young scientists, to do this. They see the grand examples of the Pinkers and the Dawkins and think, 'I can do that', and they're going to find that that may be the end of their career. You still have to earn your brownie points by publishing in the right journals and doing the right things. (R10 - academic, sociobiology, psychology; popular author) ${ }^{\mathrm{xxx}}$

Overenthusiastic, excessive or premature (in terms of the science or of the career of the scientist) popular discussions of science can still be seen as illegitimate, especially from within the academic arena. This meant that rhetorical manipulation of the category 'popular science' occurred throughout evolutionary psychology debates, despite the obvious influence of popular books in the area. For example, in this review of Alas Poor Darwin (2000), evolutionary psychologist Geoffrey Miller critiques the book for focusing only on the 'popularized' version of evolutionary psychology while ignoring the 'real science' in academia:

The "evolutionary psychology" castigated here is not the modern science of human nature as it is actually developing, but a simplified, out-dated, third hand version that focuses too much on the writings of the field's best known popularisers such as Steven Pinker, David Buss, Matt Ridley and Dan Dennett. (Miller, 2000b)

However, when doing popular work, those aspects of evolutionary psychology seen as most relevant to people's everyday lives must be further emphasized in order to boost the subject's popular appeal. Therefore, evolutionary psychology's problematic boundaries between science, politics and everyday knowledge must be pushed even further by the move into the public domain. When discussing popular evolutionary psychology, both academics and media professionals felt the need to draw a line between 'good' and 'bad' popular science, by putting forward examples that, for them, fell outside the boundaries of legitimacy.

And there's all that rather dubious stuff about hip to waist ratios, which I have to say I find some of the least convincing of all this stuff, let alone Thornhill and whatsisname on rape, which is just kind of... [trails off]. And of course those people let the side down horribly; I was trying to tell $\mathrm{X}$, that rape book was just... [again lost for words] And of course the media love that! Because it's so over the top, and explosive and all that, it's kind of the more sensible you are the less interested they are in you. (R13 - nonfiction publishing editor) ${ }^{\mathrm{xxx}}$

Importantly, this also shows how scientific boundary work is carried out not only by scientists and scientific institutions, but also by and in the interests of actors throughout society. 


\section{Discussion and conclusions}

Since the early 1990s, evolutionary psychology has challenged, reconstituted or reinforced boundaries within and around the sciences at almost every level: in the complex disciplinary ecology around studies of evolution and humans; within the social sciences; at their interface with the natural sciences; and at the demarcations made between science and the rest of society. At the same time, evolutionary psychologists have made concerted efforts to make their arguments in the public domain of the UK media, through writing popular books and press articles, giving public lectures, and appearing on television and radio programs. This has also happened with academics and others who disagree with evolutionary psychology claims, creating a public controversy which continued through the late 1990s and early 2000s. Crucially, the evolutionary psychology controversy has been a highly interdisciplinary one, involving academics and writers from across the natural sciences, social science and humanities.

As I described earlier, a growing body of research in sociology and history of science has traced links between discussions of science in the public domain, the establishment of legitimacy for research activities, and the boundary work carried out within and around the sciences. However, to simply outline the co-incidence of interdisciplinary conflict and public discussion in the case of evolutionary psychology is not really sufficient to make the case that they are linked. As I described earlier, other factors, such as the relevance of evolutionary psychology arguments to everyday life and to contemporary political issues, have probably also contributed to pulling the subject into the public domain of the mass media, and I will be exploring these suggestions in my ongoing work. However, one thing that boundary work and public science do have in common is audiences: the people evolutionary psychologists and their opponents were attempting to convince in making their arguments. As Massimiano Bucchi has argued, in cases of deviation, 'popular science' is often not exclusively aimed at the wider 'public' at all, citing the cold fusion case as a prime example of this:

In such a case one could even argue that, just as happens for a certain form of political discourse, scientists' discourse at the public level is only apparently 'public': communication at this level is not actually meant to address the public, but to send 'coded messages' to colleagues without having to conform to the constraints of specialist communication. (Bucchi, 1996; p380)

Although this study can say nothing about the actual audiences or publics of popular evolutionary psychology, it has been possible to investigate what the intended audiences were: the social worlds that actors in popular evolutionary psychology were attempting to reach. In the UK, coverage of evolutionary psychology was not spread evenly across the entire mass media, but was instead largely concentrated in specific sites, such as the broadsheet press, news magazines, and upmarket broadcasting sites with elite audiences, such as Channel 4 and Radio 4 (Cassidy, 2005). When asked who they believed the audiences for popular evolutionary psychology were, both academics and media professionals gave an initial response that they had no idea what or who the audiences for EP were. However, many would continue by discussing their intuitions of who they 
thought or hoped that they were talking with. For academics, publishers and journalists alike, the most frequently mentioned audience was an elite, professional educated one, and invariably the idea of academics and scientists as audiences was seen as extremely important:

So that's why the other academics read these books: if you ring up, if I ring up any of my academic colleagues, prominent academics, the first thing we'll talk on the phone is, 'have you read the new book by Matt Ridley, or Mark Ridley?' or, 'have you read the latest book by Brian Greene?', or 'what's Richard Dawkins' latest book like?' Academics are reading those books, so that's where the debate is happening. (R6 - academic, evolutionary psychology; popular author)

Furthermore, popular authors described how, for them, popular writing could be helpful for their work in other ways, recalling the way in which Ulrike Felt (2000) has described the public domain as a creative space for scientists, in which they can develop ideas in a more speculative fashion than is allowable in academic journal publications.

But when I do popular science writing, I write with a popular science hat on, and to some extent, they're much more relaxed and I don't claim that the research underpinning them is meticulous, and I don't intend it to be. So something like [book title], I wrote it in three months. Now that was written kind of because it was fun to do, and it was an interesting story to talk about, but also in the process I was kind of trying to pull a whole load of disparate ideas together in my own mind, all these things I'd been doing, trying to make sense of them, and academically that's what that book did, but it was really written to entertain. (R5 - academic, behavioural ecology, evolutionary psychology; popular author)

Therefore, UK actors in popular evolutionary psychology themselves understood it to be a public scientific debate, one which could not occur in academia for a number of reasons. As well as the fact that both the content of and participants in this debate cut completely across pre-existing disciplinary structures in academia, the theoretical and at times speculative nature of evolutionary psychology was also a significant barrier to academic discussion of the subject.

'Evolutionary psychology' was initially a term used by a distinct group of (largely US based) academics emerging from the sociobiology community in the late 1980s and early 1990s. Unlike their predecessors, who were largely located in the biological natural science disciplines, these researchers worked in social science subjects such as cognitive psychology, and argued for a distinctive approach: a 'new paradigm', for both the social sciences and for evolutionary studies of humans. The use of 'evolutionary psychology' as a label signalled both this distance from previous approaches, and its location in the social sciences, whilst at the same time arguing strongly against other approaches within the social sciences. A rapid move into the public domain, through popular science books and public lectures, enabled them to develop their ideas and reach new allies in the $\mathrm{UK}$ and in their own and other disciplines, at a stage when there was relatively little academic discussion of the subject (Cassidy, 2005). These allies, particularly members of the Darwin@LSE group in the UK, then continued to communicate in the public domain, not only by producing more popular science and developing their ideas in this space, but also by networking between a diverse group of academics and media 
professionals, including journalists and publishers. Following this, a number of academics and writers, working from a range of disciplines also mobilised in the public domain, for a variety of reasons, including protection of their own subject, disagreement with the specific approach taken by evolutionary psychologists, or political objections to the claims being made. This resulted in an atmosphere of debate in media such as the press and popular science books, but also a wider recognition of the term. In recent years, it seems that there has been a broadening of the meaning of 'evolutionary psychology', to encompass most contemporary evolutionary approaches to studying humans. This means that, although initial moves into the public domain have been successful in creating evolutionary psychology as a label that is widely recognised by academics, media professionals and perhaps wider publics, the meaning of that label has shifted and continues to do so, changing and developing over time.

Evolutionary psychology, as it appeared in the public domain of the UK, appears to be a good example of Bucchi's (1996) 'deviation processes' in science communication. Such processes are not necessarily 'deviant' as such, but do not occur on a regular basis, and when they do, it is usually under specific circumstances. As this and my previous paper have shown, evolutionary psychologists moved into the UK media, putting their arguments directly in the form of popular science books, newspaper articles, book reviews, public lectures, and broadcast appearances. In the early 1990s, evolutionary psychology was a new approach to the evolutionary study of humans, positioning itself as distinct from forerunners such as Sociobiology, through its theoretical approach, empirical methodologies, and locations in the social sciences and humanities. As I have described here, evolutionary psychology contested scientific boundaries at almost every level, from the immediate 'disciplinary ecology' surrounding it, right up to the traditional distinctions made between science and 'non-science' (by moving so actively into the public domain). For similar reasons to the evolutionary psychologists', academics and authors with other positions also moved into the public domain to contest evolutionary psychology claims and boundary definitions. Unlike examples such as cold fusion, evolutionary psychologists initially published their work in academic fora, on a small scale, but then used mass media and popular science forms to reach broader, multidisciplinary audiences. This process is particularly evident in citation rates for some popular books, the rise in academic citations subsequent to media coverage of the subject, and the interview discussions quoted here. Interestingly, evolutionary psychology textbooks have only started to appear in recent years (e.g. Barrett, Dunbar and Lycett, 2001), signifying a degree of academic maturity which did not exist in the previous decade. As this paper has shown, both academics and media professionals involved with popular evolutionary psychology in the UK themselves had a very good understanding of these processes, grounded in their own experiences and intentions of doing popular science.

\section{Acknowledgements}

The research leading up to this paper was supported by studentships from the ESRC held at the University of Edinburgh, while the writing of this paper was supported by an ESRC Postdoctoral Fellowship held at the University of Manchester. I would like to express my 
gratitude for the advice and support of my doctoral supervisors Dr. Wendy Faulkner and Dr. Steve Sturdy of the University of Edinburgh. Thanks also to the staff and students of CHSTM, University of Manchester, for their support, interest in and suggestions about my work, to two referees from Public Understanding of Science and to my interviewees without whom this work would not be possible.

Permissions for reproductions of images have been given with many thanks from: William A. Spriggs of Evolution's Voyage; Marco Nani of A Field Guide to the Philosophy of Mind; Phil Mole and Marc Abrahams of Annals of Improbable Research, for 'The Evolutionary War'. 
In press for a forthcoming issue of Public Understanding of Science: please do not cite or quote

\section{Bibliography}

Angier, N. (1999) Woman: an Intimate Geography. London: Virago Press.

Ashmore, M. and Richards, E. (1996) (eds) 'The Politics of SSK: Neutrality, Commitment and Beyond' Special Issue, Social Studies of Science, 26(2): 219-391.

Barkow, J., Cosmides, L. \& Tooby, J. (1992) (eds.) The Adapted Mind: Evolutionary Psychology and the Generation of Culture. New York; Oxford: Oxford University Press.

Barrett, L., Dunbar, R.I.M. \& Lycett, J. (2001) Human Evolutionary Psychology.

Basingstoke: Palgrave.

Bateson, P. and Martin, P. (1999) Design for a Life: Explaining Human Development. London: Jonathan Cape.

Birkhead, T. (2000) Promiscuity: an evolutionary history of sperm competition and sexual conflict. London: Faber.

Bloor, D (1991) Knowledge And Social Imagery ( $2^{\text {nd }}$ edition). Chicago: University of Chicago Press

Brockman, J. (1995) The Third Culture: Beyond the Scientific Revolution. London; New York: Simon and Schuster.

Brooks, M. (1998) May the best man win: Some evolutionary pugilists seem to be just too proud to give up. New Scientist, 2129,11 ${ }^{\text {th }}$ April 1998: 51

Brown, A. (1999) The Darwin Wars: How Stupid Genes Became Selfish Gods, London; New York: Simon \& Schuster.

Brewer, J and Hunter, A (1989) Multimethod Research: A Synthesis of Styles. Thousand Oaks, Calif.; London: Sage Publications

Bucchi, M. (1996) When scientists turn to the public: alternative routes in science communication. Public Understanding of Science, 5, 375-94.

Bucchi, M. (1998) Science and the Media: Alternative Routes in Science Communication. London: Routledge.

Buss, D. (1995) Evolutionary psychology: A new paradigm for psychological science. Psychological Inquiry, 6, 1-30.

Cassidy, A. (2005) Popular evolutionary psychology in the UK: an unusual case of science in the media? Public Understanding of Science, 14, 115-41

Caudill, E. (1989) Darwinism in the Press: The Evolution of an Idea. New Jersey; London: Lawrence Erlbaum Associates

Clarke, A.E. (1990) A Social Worlds Research Adventure. In Cozzens, S.E. and Gieryn, T.F. (eds.) Theories of Science in Society, p15-42. Bloomington \& Indianapolis: Indiana University Press.

Clarke, A.E. (1998) Disciplining Reproduction: Modernity, Life Sciences, and "The Problems of Sex". Berkeley: University of California Press.

Clemens, E.S. (1986) Of asteroids and dinosaurs: the role of the press in shaping scientific debate. Social Studies of Science, 16, 421-56.

Cloitre, M. \& Shinn, T. (1985) 'Expository practice: social, cognitive and epistemological linkages' In: Shinn, T. \& Whitley, R. (eds.) Expository Science: Forms and Functions of Popularisation, p31-60. Dordrecht: Reidel.

Collins, H.M. (1985) Changing Order: Replication and Induction in Scientific Practice. London: Sage.

Collins, H.M. and Evans, R. (2002) The Third Wave of Science Studies: Studies of Expertise and Experience. Social Studies of Science, 32(2), 235-296. 
In press for a forthcoming issue of Public Understanding of Science: please do not cite or quote

Collins, S. (2000) Redrawing Rape: Boundary Work in Thornhill and Palmer's "A Natural History of Rape" Unpublished MSc dissertation, London: Imperial College of Science, Technology and Medicine.

Cooter, R. (1984) The Cultural Meaning of Popular Science: Phrenology and the Organisation of Consent in Nineteenth Century Britain (Cambridge History of Medicine Series). Cambridge: Cambridge University Press.

Cosmides, L. \& Tooby, J. (1997) Evolutionary Psychology: A Primer [Online]. Available: http://www.psych.ucsb.edu/research/cep/primer.html, Santa Barbara, CA: Centre for Evolutionary Psychology, UCSB, accessed on 05/03/01.

Cronin, H. (1999) 'It's only natural: the biological differences between men and women are no threat to feminism' Red Pepper (March 1999).

Cronin, H. and Curry, O. (2000) 'Pity poor men' The Guardian, February $5^{\text {th }} 2000$

Curry, O. (1997) In conversation with Richard Dawkins. In the evolutionist [Online] Available: http://www.lse.ac.uk/Depts/cpnss/darwin/evo/dawkins.htm, accessed 23/07/04.

Curry, O., Cronin, H. and Ashworth, J. (1996) (eds.) 'Matters of life and death: the world view from evolutionary psychology’ Demos Quarterly, 10 London: Demos Darwin, C. (1859) On the origin of species. London: John Murray.

Dawkins, R. (1976) The Selfish Gene. Oxford: Oxford University Press.

Dennett, D.C. (1997) Darwinian Fundamentalism: An Exchange. New York Review of Books, $14^{\text {th }}$ August 1997

Dolby, R.G. (1982) On the autonomy of pure science: the construction and maintenance of barriers between scientific establishments and popular culture. Sociology of the Sciences Yearbook VI, 267-292.

Dunbar, R. (1995) The Trouble With Science. London: Faber

Dunbar, R. (1996) Grooming, Gossip and the Evolution of Language. London: Faber

Dusek, V. (1999) Sociobiology Sanitised: the Evolutionary Psychology and Genic Selectionism Debates. Science as Culture, 8(2), 129-170.

Evans, D. \& Zarante, O. (1999) Introducing Evolutionary Psychology. Cambridge: Icon Books.

Felt, U. (2000) Why should the public "understand" science? A historical perspective on aspects of the public understanding of science. In Dierkes, M. \& von Grote, C. (eds.) Between Understanding and Trust: The Public, Science and Technology, p7-38.

Amsterdam: Harwood Academic Publishers.

Fodor, J.A. (1983) The Modularity of Mind: An Essay on Faculty Psychology.

Cambridge, MA; London: MIT Press.

Fodor, J.A. (2000) The Mind Doesn't Work That Way: The Scope and Limits of Computational Psychology. Cambridge, MA; London: MIT Press.

Gaziano, E. (1996) 'Ecological Metaphors as Scientific Boundary Work: Innovation and Authority in Interwar Sociology and Biology' American Journal of Sociology, 101(4): 874-907

Giddens, A. (1999) The Relevance of the Social Sciences. The Director's Home Page [Online]. Available: http://www.lse.ac.uk/Giddens/school2000.htm, London: London School of Economics, accessed online on 10/06/03.

Gieryn, T.F. (1983) Boundary work in professional ideology of scientists. American Sociological Review, 48, 781-95. 
Gieryn, T.F. (1985) Professionalization of American Scientists: Public Science in the Creation/Evolution Trials. American Sociological Review, 50, 392-409.

Gieryn, T.F. (1999) Cultural Boundaries of Science: Credibility on the Line. Chicago: University of Chicago Press.

Gilbert, G. \& Mulkay, M. (1984) Opening Pandora's Box: a sociological analysis of scientists' discourse. Cambridge: Cambridge University Press.

Goodell, R. (1977) The Visible Scientists. Boston: Little, Brown.

Gould, S.J. (1997a) Darwinian Fundamentalism. New York Review of Books, $12^{\text {th }}$ June 1997.

Gould, S.J. (1997b) Evolution: The Pleasures of Pluralism. New York Review of Books, $26^{\text {th }}$ June 1997.

Habermas, J (1992) The Structural Transformation of the Public Sphere: An Enquiry into a Category of Bourgeois Society (trans. by Berger, T). Cambridge and Oxford, first published in German, 1962

Haraway, D. (1986) Primatology is Politics by Other Means. Ch. 5 in Bleier, R. (ed.) Feminist Approaches to Science, p77-118. New York; Oxford: Pergamon.

Herrnstein, R.J. and Murray, C. (1994) The Bell Curve: Intelligence and Class Structure in American Life. New York, London: Free Press

Hrdy, S.B. (1999) Mother Nature: Natural Selection and the Female of the Species. London: Chatto and Windus.

Hughes, J. (1990) The Philosophy of Social Research (2 ${ }^{\text {nd }}$ edition). London: Longman.

Jones, S. (1999) Almost Like A Whale: 'The Origin of Species' Updated. London: Doubleday.

Kuhn, T.S. (1962) The Structure of Scientific Revolutions. Chicago: University of Chicago Press.

Kurzban, R., Tooby, J. \& Cosmides, L. (2001) Can race be erased? Coalitional computation and social categorisation. Proceedings Of The National Academy of Sciences Of The United States Of America, 98(26), 15387-15392.

Latour, B. (1987) Science In Action: How to Follow Scientists and Engineers Through Society. Cambridge, MA: Harvard University Press.

Lewenstein, B. (1995a) From fax to facts: communication in the cold fusion saga. Social Studies of Science, 25, 403-36.

Malik, K. (2000) Man, Beast and Zombie: What Science Can and Cannot tell us About Human Nature. London: Weidenfeld and Nicholson.

Mellor, F. (2003) Between 'fact' and 'fiction': demarcating science from non-science in popular physics books. Social Studies of Science, 33(4), 509-538.

Miller, G. (2000a) The Mating Mind: How Sexual Choice Shaped the Evolution of Human Nature. Oxford: Heinemann.

Miller, G. (2000b) Taking a pop at psychology. Evening Standard, $3^{\text {rd }}$ July 2000.

Phillips, D.M., Kanter, E.J., Bednarczyk, B. and Tastad, B.L. (1991) Importance of the lay press in the transmission of medical knowledge to the scientific community. New England Journal of Medicine, 325(16), $11^{\text {th }}$ October 1991: 1180-3.

Pinker, S. (1997) Evolutionary Psychology: An Exchange. New York Review of Books, $9^{\text {th }}$ October 1997.

Pinker, S. (1998) How the Mind Works. London: Allan Lane. 
In press for a forthcoming issue of Public Understanding of Science: please do not cite or quote

Planck, M (1949) Scientific Autobiography and Other Papers, trans. F. Gaynor (New York, 1949), pp.33-34. As cited in Kuhn, T.S. (1996) The Structure of Scientific Revolutions, Third Edition. Chicago: University of Chicago Press

Radcliffe Richards, J. (2000) Human Nature after Darwin: A Philosophical Introduction. London; New York: Routledge.

Rees, A. (2001a) Anthropomorphism, Anthropocentrism, and Anecdote: Primatologists on Primatology. Science, Technology and Human Values, 26(2), 227-47.

Rees, A. (2001b) Practising Infanticide, Observing Narrative: Controversial Texts in a Field Science. Social Studies of Science, 31(4), 507-31.

Richards, G. (2002) Putting Psychology in its Place: A Critical Historical Overview $\left(2^{\text {nd }}\right.$ edition). Hove: Routledge.

Rodgers, M. (1992) The Hawking phenomenon. Public Understanding of Science, 1, 231-34.

Rose, H. (2000) Colonising the Social Sciences? Ch. 7 in Rose, H. \& Rose, S. (eds.) Alas Poor Darwin: Arguments Against Evolutionary Psychology, p106-128. London: Jonathan Cape.

Rose, H. \& Rose, S. (2000) (eds.) Alas, Poor Darwin: Arguments Against Evolutionary Psychology. London: Jonathan Cape.

Royal Society (2001) New Fellows, Foreign Members and Honorary Fellows, 2001. Media release, $14^{\text {th }}$ May 2001 [Online]. Available at:

http://www.royalsoc.ac.uk/templates/press/releasedetails.cfm?file=316.txt, accessed on 09/06/03.

Segal, L. (1999) Why Feminism? Gender, Psychology, Politics. London: Polity Press.

Segerstrale, U. (2000) Defenders of the Truth: The Battle for Science in the Sociobiology Debate and Beyond. Oxford: Oxford University Press.

Shapin, S. (1979) 'The Politics of Observation: Cerebral Anatomy and Social Interests in the Edinburgh Phrenology Disputes'. In Wallis, R (ed.), On the Margins of Science:

The Social Construction of Rejected Knowledge. Sociological Review Monograph, 27: 139-178. Keele: Keele University Press.

Simon, B. (2001) Public science: media configuration and closure in the cold fusion controversy. Public Understanding of Science, 10, 383-402.

Singer, P. (1999) A Darwinian Left: Politics, Evolution and Cooperation (Darwinism Today). London: Weidenfeld and Nicholson.

Singh, D (1993) Adaptive significance of female physical attractiveness: Role of waistto-hip ratio. Journal of Personality and Social Psychology, 65(2): 293-307.

Star, S.L. \& Griessemer, J.L. (1989) Institutional Ecology, "Translation" and Boundary Objects: Amateurs and Professionals in Berkeley's Museum of Vertebrate Zoology, 1907-1939. Social Studies of Science, 19, 387-420.

St. John, W. (1999) Agent Provocateur: John Brockman - literary impresario, idea guy, brat - is on a mission to force book publishing to accept its digital destiny. Wired Magazine, Issue 7.09, September 1999.

Thornhill, Randy and Palmer, Craig T (2000) A Natural History of Rape: Biological Bases of Sexual Coercion. Cambridge, MA; London: MIT Press

Tierney, P. (2000) Darkness in ElDorado: How Scientists and Journalists Devastated the Amazon. New York: Norton.

Toolis, K. 'Race to the right' The Guardian, 20 ${ }^{\text {th }}$ May 2000. 
In press for a forthcoming issue of Public Understanding of Science: please do not cite or quote

Turner, F.M. (1980) Public science in Britain, 1880-1919. Isis, 71, 589-608.

Wilson, E.O. (1975) Sociobiology: The New Synthesis. Cambridge, MA; London: Harvard University Press.

Wilson, E.O. (1998) Consilience: The Unity Of Knowledge. London: Little, Brown.

Wright, R. (1994) The Moral Animal: Evolutionary Psychology and Everyday Life. New York: Pantheon; (1995) The Moral Animal: The New Science of Evolutionary Psychology London: Little, Brown. 
In press for a forthcoming issue of Public Understanding of Science: please do not cite or quote

\section{Notes}

iI would see this shift into 'the public domain' of the mass media to be very much in the vein of a move towards acting in Habermas' modern 'public sphere' (Habermas, 1992).

${ }^{\text {ii }}$ New Scientist and Scientific American are very well known examples of popular science media. In a similar vein, Annals of Improbable Research (AIR) is a US based science humour magazine with a prominent web presence, see http://www.improbable.com/ for further details. In addition, the genre of popular science books can be seen similarly as science books with a shared audience of academics and 'interested lay' readers.

iii See also Brooks (1998, p51) for similar use of this metaphor in discussion of a public spat between Stephen Jay Gould and evolutionary psychologist Steven Pinker (see Dennet, 1997; Gould, 1997a; 1997b; Pinker, 1997 for further details).

iv To give a sense of scale, Hawking's A Brief History of Time has only 7 citations in the ISI's Web of Science database, whereas Dawkins's Selfish Gene, now over 25 years old, also a popular science classic, has over 1,500 in the past ten years alone, giving a strong indication of each book's influence in academia. ${ }^{v}$ Interview sources are cited with respondent (R) number, occupation and academic subject where appropriate. A total of twenty one semi-structured interviews were carried out over 1999 and 2000, twelve of which were with academics and nine with media professionals.

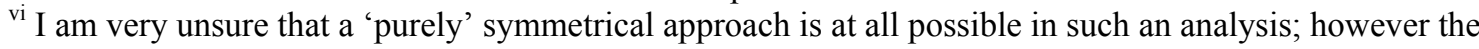
process of attempting it has proved to be invaluable in carrying out this research.

${ }_{\text {vii }}$ It would be very difficult to give a more accurate estimate because of the problems in defining what can count as an 'evolutionary psychology' book.

${ }^{\text {viii }}$ In this text, I use 'sociobiology' to refer to the academic field of study by that name, including its modern forms; 'Sociobiology' denotes the original controversy of the 1970s surrounding the publication of Wilson's book Sociobiology: The New Synthesis (1975).

${ }^{\mathrm{ix}}$ John Brockman is a publishing agent, who represents many of the most famous and successful popular science academic authors, including Richard Dawkins and Steven Rose. He is particularly famous for securing some very large (six figure) advances from publishers for popular science books (see St. John, 1999).

x Examples of such trends within popular science publishing might include 'religiously' themed physics books, or popular science history.

xi The choice of 'Darwin@LSE' as a title seems to reflect the group's orientation towards modernism, science and technology, as well as the then dramatic rise of the Internet as a force in popular culture (see also their use of the lowercase the evolutionist as a title for an online magazine, and their links with John Brockman and Edge magazine, discussed below. See the Darwin@LSE website at http://www.lse.ac.uk/Depts/cpnss/darwin/index.htm for further details.

xii Interview, R6 - academic, evolutionary psychology; popular author

xiii Darwin@LSE was originally funded by several charitable foundations and private sponsors, and the public programme eventually closed for a combination of financial and personal reasons, whilst "work in progress' meetings and private research continues to be undertaken. See: 'Darwin@LSE: The story so far...' at http://www.lse.ac.uk/Depts/cpnss/darwin/story.htm.

${ }^{\text {xiv }}$ Media coverage of evolutionary topics in general is often linked with such 'hooks', particularly Darwin anniversaries, such as the date of his death, or publication of the Origin (Caudill, 1989).

${ }^{\mathrm{xv}}$ Although this ecological metaphor might be seen as potentially problematic in a study of relations between the natural and social sciences, it is widely used in social worlds research, and by no means implies that society operates in exactly the same way as an ecology. Furthermore, it is worth noting that sociologists have used the ecological metaphor before, in the early part of the $20^{\text {th }}$ century, and in particular used it to help open up a space for distinctly sociological enquiry, rather than allowing it to be reabsorbed into the natural sciences (Gaziano, 1996).

${ }^{x v i}$ For the record, I have an undergraduate training in psychology and zoology (largely carried out prior to evolutionary psychology's establishment in its current form); but a postgraduate training in sociology and science studies. I would consider myself to be a social researcher who uses a qualitative-interpretive research approach in conjunction with quantitative methodologies. 


\footnotetext{
xvii See http://www.hbes.com/ and http://www.science.mcmaster.ca/psychology/ehb/ehb.htm for further details of these. Evolution and Human Behaviour changed its name from Ethology and Sociobiology in 1996.

xviii Evolutionary Psychology' (Buller, 1998) on the website A Field Guide to the Philosophy of Mind http://host.uniroma3.it/progetti/kant/field/ep.htm

xix 'What is Evolutionary Psychology?' on the website Evolution's Voyage by William A. Spriggs. http://www.evoyage.com/Whatis.html

${ }^{\mathrm{xx}}$ Interestingly, phrenology itself had enormous popular appeal and was also the subject of huge controversy in the public domain, as well as heavy boundary work during the nineteenth century (see Cooter, 1984; also Shapin, 1979).

${ }^{x x i}$ The use of lowercase font for the evolutionist magazine was purposeful: see note 10 above.

${ }^{x x i i}$ Several textbooks recently published on evolutionary psychology have actually stressed precisely this theme of a 'broad church' coming together under the label, see, e.g. Barrett, Dunbar and Lycett (2001).

xxiii This e-mail distribution list regularly posts details of new research and media reports relevant to EP, which are then commented on by list members, many of whom are academics working in the area This list is available to members of the public, but by request only. It has been running since 1999 and at the time of writing has a little over 3,500 members, largely in the US and UK. For further information see $\mathrm{http} / /$ groups.yahoo.com/group/evolutionary-psychology/ and http://human-nature.com/.

${ }^{x x i v}$ Wilson has built upon and elaborated these ideas in his more recent work, Consilience (Wilson, 1998).

${ }^{x x v}$ A good example of this would be the controversy in 2000 over a book, Darkness in El Dorado (Tierney, 2000), alleging that physical anthropologist and sociobiologist Napoleon Chagnon engaged in widespread abuses of the Yanomamo Indians he studies. These claims resulted in bitter disputes between physical and social anthropologists, including prominent evolutionary psychologists such as John Tooby (see his website http://www.psych.ucsb.edu/research/cep/eldorado/)

${ }^{x x v i}$ Several of the proponents of EP, such as Helena Cronin, Daniel Dennet, Janet Radcliffe Richards and Peter Singer are philosophers, while the Darwin@LSE program was located in the Centre for Philosophy of Natural and Social Science at the LSE

xxvii These connections have also been noted by Hilary Rose in her discussions of EP (Rose, 2000), as well as by Malik (2000) and Collins (2000).

xxviii See Curry, Cronin and Ashworth (1996); also Cronin and Curry, (2000) as another example of evolutionary psychology policy advice.

${ }^{x x i x}$ This is particularly crucial considering the way in which far right organisations have in the past embraced sociobiology to justify their views, and that the current leader of the BNP continues to do so with evolutionary psychology (see Toolis, 2000).

${ }^{x x x}$ John Brockman's ideas about the 'Third Culture': a public space for scientists to debate, have been very influential on some evolutionary psychologists (see Brockman 1995, and his website Edge, http://www.edge.org/).

xxxi The hip-waist ratio work refers to research findings on men's preferences for a particular kind of "curvy" female figure (e.g. Singh, 1993). Thornhill and Palmer (2000) argue for the evolutionary origins of male-female rape.
}

\author{
Author \\ Angela Cassidy is a Research Fellow in Risk Communication at Leeds University \\ Business School. Her PhD, completed in 2003 at the University of Edinburgh, was \\ entitled, "Of Academics, Publishers and Journalists: Popular Evolutionary Psychology in \\ the UK". Her research interests include relationships between expertise and 'lay' \\ knowledge; popular science and science communication; gender and science;
}


In press for a forthcoming issue of Public Understanding of Science: please do not cite or quote

contemporary evolutionary debates; and the combination of quantitative and qualitative research methodologies.

Address: Leeds University Business School, Maurice Keyworth Building, University of Leeds, Leeds, LS2 9JT; phone: 0113384 6080; email: a.m.cassidy@leeds.ac.uk; angela.cassidy@gmail.com 